\title{
上野公園における公的儀式とその空間形成への影響
}

\section{Public Ceremonies and its Effect on Spatial Developements of Park, in a Case of Ueno Park}

小野良平*

Ryohei ONO

\begin{abstract}
摘要：東京の上野公園は，明治初期に内務省の主導の下，博物館事業や内国勧業博覽会を推進する国 家的公園として開設された。本稿では, 明治期の国家的イベントとして最も重要である天皇が臨幸し た儀礼的行為に着目し、たびたびその会場となった上野公園を対象に明治期の公園の空間構造の形成 に及ほした影響について考察した。現在に至る空間の骨格は明治初期に形成され，はじめに上野に国 家的性格を与える儀礼が行われ，つづいて天皇を視覚化して国民に示すという政治的要請が，公園の 空間的特性を規定する一要因となったこと等が明らかになった。
\end{abstract}

\section{1.はじめに}

太政官布告に基づいて設置された東京の上野公園に関しては, その誕生前後の複雑な経緯や，博覧会場を主としたイベント 空間としての性格等についてこれまでにも詳しく研究されてい る。 ${ }^{1 / 2) 3\rangle}$ それらも指摘するように，上野公園は太政官制公園の 中でも，唯一内務省（のち農商務省，さらに宮内省）の管轄下に あった国家的性格の強い特別な存在であった。事実，博物館事業 の展開やそれと連携した内国勧業博覧会などの開催が，現在にい たる上野公園の特質を強く規定づけていることは疑いの余地がな い。本稿ではその「国家的性格」をさらに多面的に捉える一視点 として, 連綿と続く公園事業展開の中にも突出した形で現れた, 出来事としての国家的儀礼行為に着目する。特に明治天皇による 行幸に代表される公的儀礼行為（表一1）は，それが行われた意 味はもちろんのこと, 実際の儀式のディテールに至るまでが，近 代天皇制の下での「近代の国民」の形成に強く関わっていた事か 指摘されている。年5〉それは実際に儀式を演じる器としての都市 空間にも形を伴って影響を与えたに違いない。本稿はそのような 「政治の空間デザイン」の一端を知るべく，儀式の場としての公 園の利用が，その後の公園の地域における位置づけや公園そのも のの空間構造の形成によ゙のような影響を与えたかを上野公園を対 象として考察することを目的とする。

\section{2. 上野公園開園式（明治 9 年）}

明治 6 年に既に公園として決定されていた上野公園に，明治 9 年 5 月 9 日，明治天皇は「開園につき行幸」6)した。これは明治 9 年 1 月に上野公園が紆余曲折の末，内務省の管轄となり博覧会 及び博物館事業の道を進み始めたことを受けての行事といえ，国 家的性格を考察する上では軽視できない出来事である。この行幸 は一般に上野公園の開園式といわれている”が，しかし何点かの 資料を当たっても，奉迎のための軍楽隊の奏楽程度はみられるむ のの,「式典」と呼ぶべき儀式が行われた形跡はない。6/8/97103

各資料に若干相違はあるが総合すると，天皇皇后はまず慈眼堂 を訪れ茶果で休息し, その後東漸院, 徳川将軍の霊廟を巡覧, さ らに精養軒に立寄り最後に山王台を降りて皇居に戻っている。 （図-1）これらの場所はそれぞれに興味深い。まず慈眼堂は, 寛永寺の開祖であり, 徳川家康・秀忠・家光の側近として仕えた 慈眼大師・天海を祀る寺院である。この天海は, 江戸城の鬼門の
艮に政山を見立てて東跈山寛永寺を興し，同様に裹鬼門に増上寺 を移転するなど，いわば宗教空間上のデザインにより，江戸の都 市計画に大きく関与した大僧正である。”実体としての上野公園 の整備はほとんど進んでいなかったが，便殿（行幸の際の仮設休 憩所）を設けることもせず，行幸が第一に慈眼堂を目指したこと は，単に戊辰戦争で残った建物を休噭所として使用したものとは 考えにくい。続いて徳川廟を訪れたことも含め, 江戸・徳川の遺 した上野という土地の意味に対する何らかの儀礼的意思の表れ之 見ることができる。明治 2 年には皇居内紅葉山の徳川廟等が撤去 された一方で, ${ }^{12)}$ 上野においては徳川廟や東照宮が残されたこ之 自体もさることながら，天皇がその霊廟を上野訪問の手始めに訪 ねたことは，単なる巡覧以上の儀礼であったことを示している。

他の巡覧地点の東漸院, 精養軒, 山王台はいずれも東, 西, 南 を望む眺望地点である。上野台地から展望可能な全方位を天皇は 見渡した。明治元年の天皇の東幸以来, 天皇が高台から江戸一東 京の町を眺めた記録はこのときまで見られない。(3) いわばこれは 天皇の「国見」行為であった。国見之は古代の儀礼に限られたも のではなく, たとえば昭和天皇は, 関東大震災後の東京の復興の 様子を同じ上野公園の山王台から「御展望」した。内務省直轄 地として博物館等の事業を始めるに当たり, 上野の場所性を活か しながらも新たに意味を更新するため, これらの天皇の儀礼行為

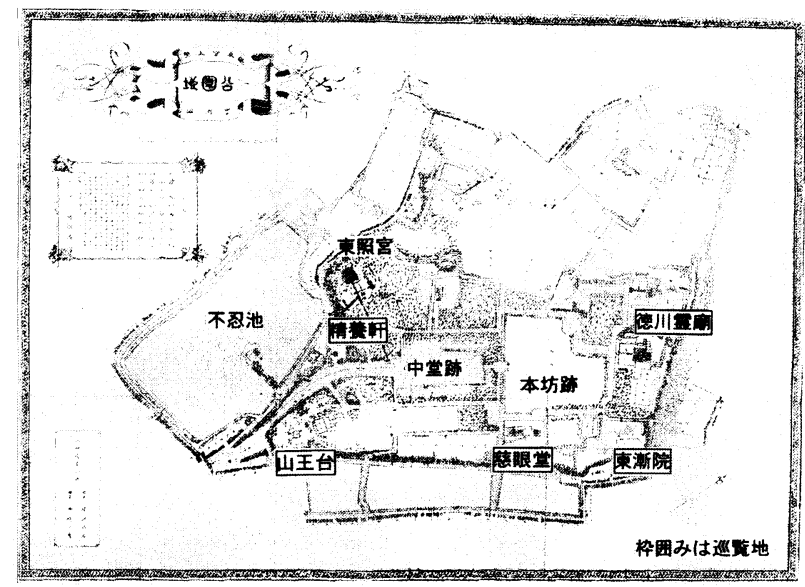

図－1 上野公園開園式での巡覧地（明治10年実測図より）

·東京大学大学院農学生命科学研究科 


\begin{tabular}{|c|c|c|c|c|c|c|}
\hline \multicolumn{2}{|c|}{ 年 } & 月 日 & 上野公國への行萃 & その他䦕戛する行幸 & 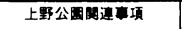 & その他间壝项 \\
\hline 1868 & M 1 & 10.13 & & 真幸、毫京城若 & 戊辰新争 & \\
\hline 1872 & M 5 & $5.23-7.12$ & & 近僼中国九州行幸 & & \\
\hline 1873 & M 6 & & & & 太政官布告(1月) & ウィーン加 \\
\hline 1876 & M 9 & & & & 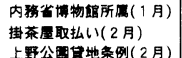 & フィラデルフィア槽卷加 \\
\hline & & & 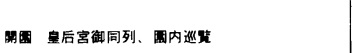 & & 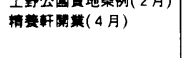 & \\
\hline 1877 & M10 & $\begin{array}{l}6.2-7.21 \\
8.21 \\
10.26\end{array}$ & 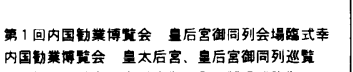 & 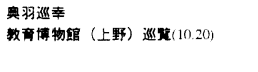 & & 西南神争 \\
\hline $187 x$ & M11 & $\begin{array}{l}11.30 \\
4.8\end{array}$ & 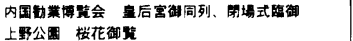 & 北辟車海巡幸(831-119) & 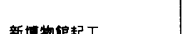 & 大久保利通喓数 \\
\hline 1879 & $M_{12}$ & 8.25 & 東京府十五区人民の相によりグラント同伴，行幸 & & 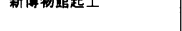 & コレラ全国に㛺延 \\
\hline 18861 & M13 & $6.16-7.26$ & & 山栔三面及ひ婛部避幸 & & \\
\hline 1881 & M14 & $\begin{array}{l}3.1 \\
4.1+20,5: 16 \\
6.10 \\
6.17\end{array}$ & 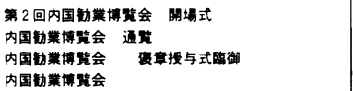 & 山形舣田北海迹通章(7.31-11.11) & 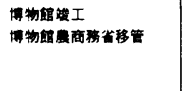 & \\
\hline 1882 & M15 & & 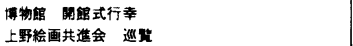 & & 助物国盟闻 & \\
\hline 1883 & M16 & $\begin{array}{l}3.27 \\
5.21\end{array}$ & 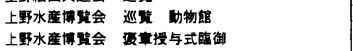 & & & \\
\hline 1884 & $\begin{array}{ll}M: 17 \\
M 18\end{array}$ & 111 & 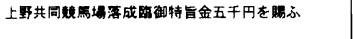 & 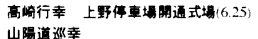 & 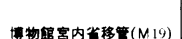 & \\
\hline $\begin{array}{l}1886 \\
1887\end{array}$ & $\begin{array}{ll}M 18 \\
M 20\end{array}$ & $\begin{array}{l}6.7 .8 .12 \\
11.12\end{array}$ & 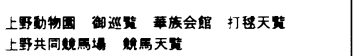 & 山吻道巡辛 & 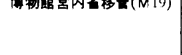 & \\
\hline 1889 & M22 & $\begin{array}{l}2.12 \\
4.15\end{array}$ & 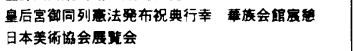 & 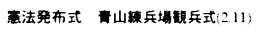 & & 大日本帝国素法発布 \\
\hline 189) & M23 & $\begin{array}{l}3.26 \\
516 \\
711 \\
731\end{array}$ & 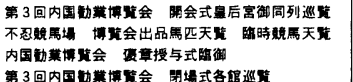 & & & \\
\hline
\end{tabular}

3 回の上野公園における 内国勧業博覧会だけでな く, 京都 (明治 28 年), 大 阪 (明治36年) に会場を 移してからも同様な形式 で続けられている。こう した天皇が臣民を前に開 会を宣言する式典の形式 は，明治政府が正式参加 した明治 6 年のウィーン 万国博覧会における皇帝 フランッ・ヨゼフ 1 世を 戴いた開場式の手順に似

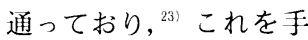
本にしたものと思われる。

そしてこの式典の空間 計画に扮ける重要性は, 単に式場か確保されてい ることではなく，馬車に よる入場から始まり，閒

が必要とされたと考えられる。壇上から栜語を述べるような一般 の式典ではなく，公園への入場から出発までの一連の天皇の身体 の動きこそが上野公園の「開園式」であった。このように天皇の パフォーマンスを切取り見ることで上野公園が開園期によ゙のよう に国家的性格を獲得していったのかを考察することができる。

この開園式に先がけて公園の馬車道，小頶所等の空間整備が若 干行われている。また内務省用地之なった直後の明治 9 年 2 月に 掛茶屋の撤去が行われたことが，博覧会を見込んでの動きである ことは既に指摘されているが, ${ }^{15)}$ 同じ 2 月，内務卵の決済によっ て「上野公園貸地条例」が定められ， ${ }^{16)}$ 割敦店や小慗所のための 貸地が行われたことは掛茶屋の撤去と表裏の関係にある。先の精 養軒もこれによって開業している。豆〉して上野公園での貸地代 が, 他の浅草, 芝, 深川の三公園の倍近い額であった ${ }^{(8)}$ 事実を 考える上，上野公園に内務省が導入しょうとした飲食店は庶民を 対象としたものではなく，天皇を迎えるに相応しい格の高いもの であったことがわかる。出苫した店が当時の博物局長, 町田久成 の肝入りであったという逸話(9) もそれを裹付けるものである。 こうして内務省の下で開園したト:野公園は, 天皇の儀礼を通して, 人民輻輳の地としての公園や上地政策としての公園とは異質の, 国家の公園として意味付けされ，実際の空間整備もわずかながら 始まり，翏明治 10 年内国勧業博覧会を迎えることになる。

\section{3. 内国勧業博覽会（明治 10,14, 23 年）}

旧宽永寺本坊跡を会場として明治 10 年に開催された第 1 回の 内国勧業博覧会に関しては，その会場計油の内外に抢ける近代性 と非近代性に関して既に分析されているが, ${ }^{20)}$ この博覧会におけ る天皇の儀礼行為，すなわち開場式及び閉場式について屯会場の 空間を規定した要因として考察する必要がある。開場式の式次第 は宮内广庁の記録21 からしか椝えないが，事務局側が残した閉場 式の細かい執行順序吕2 と残された錦絵（図一2）などから判断 して，開場式も閉場式とほぼ同様の儀式であったと思われる。

馬車による天皇の囷簿は, 儀仗兵の敬礼之軍楽隊の奏楽の中, 黑門からまっすぐ馬車道を進み，旧本坊の中門をそのまま使った 会場表門を入り，中心の建物である美術館の前面に臨時に設置さ れた式場に到着する。天皇は美術館をバックにした玉座から，大 臣，参議，奏任官，外国公使，新聞社員，及び出品人らに向けて 栜語を読み上げ，それに対し内務卿及び東京府知事が祝辞を奏上 するといった于順である。この開場閉場の式典は, 以後第 2 回,
をくぐって式場まで到達し，会場の中心的建築物である美術館を 前に勅語を発するという一連のパフォーマンスの流れそのものが 深く関与していることにある。すなわち图簿の通行に対応したス ケールの馬車道が，会場を正面から貫き，その到達先となる会場 奥には，正面性を持って配置された美術館之，その前面に式場の 開設可能な庭園的空地が確保されていることが，この儀礼を効果 的に遂行するのにふさわしい空間形式の一つであった。これは旧 寛永寺の空間構成を受け継いだものともいえるし, 上野台地の地 形から考えても寛永寺の配置に做うことが合理的であることは 確かである。 ${ }^{24)}$ しかしそれは土地の記憶に受動的に引きずられた ものだけではなく, 儀礼のための空間が会場計画を規定する大き な要因となったことは, 京都, 大阪の会場計画においても上述の

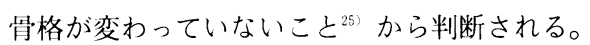

会場までのアプローチ空間では，例えば第 2 回博覧会をみると， 表門の外には両側に儀仗兵が整列して敬礼し, 入口付近には海軍 の楽隊も整列をして表門を入るまで奏楽を行う。表門を入ると中 門前に整列した陸軍の楽隊が奏楽を始め, さらに中門を入ると宮 内省の伶人が奏楽を始めるという演出がなされている。 うな演出のためには，それぞれの門に分節されながら奥へと入り 込んでいくような空間が用意されていることが効果的であり, 儀 礼の細かい作法すらもが, 上野公園のこうした空間の構造を規定 していく一要因となったのではないか。

国家による天皇の儀礼行為を意識した空間計画の最も顕著な表 れは, 美術館（第 3 回では博物館）上その前面の庭園に見ること ができる。内務卿大久保利通は, 天皇を戴く近代国家形成のため の政治技術として，天皇の可視化の必要性を強く認識していた。 それは華々しくパレードを行い, 壮麗な宮殿とその前面に広大に 展開する庭園でその権をアピールする, 西欧の絶対君主的（ル イ 14 世がその典型）政治技術に近い, ${ }^{27)}$ という考え方を援用す るなら，上野の博覧会場の美術館之前面の整形的な庭園こそが， 天皇を視覚化する儀礼の舞台道具であったといえる。（図ー - 3 ) 第 1 回の会場計画が，稚拙ながらもその意四を最も良く示してお り，公式ガイドに載せられた会場の鳥瞰図 ${ }^{28>}$ が銅版画で西欧風に 描かれたことは，来場者はむろん国内外に，メディアを通して天 皇の力を誇示しようとする技術であったといえる。そこに天皇を 直接示す記号はないにも関わらず, 儀礼を執り行う天皇を可視化 し，さらに逆に世界を睥睍する天皇の視線を生み出すことが，現 実のプラン及びその広報の双方で行われたのである。 
しかしもちろん，これらの儀礼のみが会場計画を規定したわけ ではない。例えば先のウィーン万博参加の報告書の中で, 1851 年のロンドン万博に関与した建築家による博覧会造営の方法書と いうべきものの翻訳が載せられている。吕つまり既に博覧会のた めの参照すべき空間計画論があったことも確かで，そこには例え ば会場内の「洞見」を確保すること等が, 看客 (来観者) のため の機能論などから記されている。このような天皇の儀礼に直接に は関わらない具体的計画論や博覧会当局の計画意図 ${ }^{30}$ 等も含めた, 総合的なものが会場計画には反映されていたと思われる。

\section{4. 明治 12 年の行幸（グラント将軍歓迎式）}

第 1 回博覧会の翌年の明治 11 年 4 月には, 天皇は観桜のため 上野公園を訪れているが，このときは精養軒での高官達との午餐

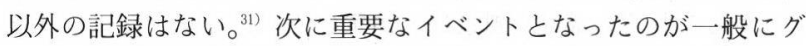
ラント将軍歓迎会 (図-4) と呼ばれている明治 12 年 8 月 25 日 の行幸である。この行幸は元々同年 7 月に, 東京府会, 十五の區 会, 商法会議所らの代表が名を連ねて下から請願を行い, これに 天皇が応じたという経緯で行われたものである。この請願者の代 表は東京府会の議長, 福地源一郎（桜痴）及び商法会議所会頭, 渋沢栄一らであった。その内容は, 明治 5 年から既に行われてい た地方巡幸にについて触れ，

（前略）然ルニ反テ帝都二住ミシ，皇居二迟尺シ，奉ルノ東京府 下十五區，人民二至リテハ, 十二年／久ヨ経ルモ未夕徳二府民， 為二御臨幸 賜ハリタルノ盛擧二値八サルハ, 抑モ府民ノ會テ是 ヨ請願シ奉ラサルノ故ナリト雖モ（中略）幸二今国家無事, 府民

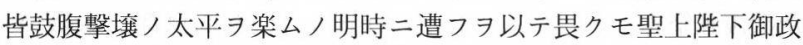
務/御㗇 7 窥イ奉リ，御臨幸 7 上野公園二恭クシ，弓馬槍剣ノ武

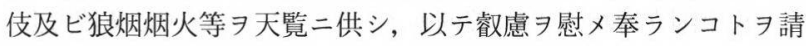
願ス。(後略 $)^{32}$

というものだった。天皇の地方巡幸とは, 明治 5 年から 18 年に かけて 6 回行われ, 明治前半の不安定な政情の中で, 生身の天皇 を民衆に見せることで天皇の存在を知らしめ, 意識下に権力を行 使して支配を強化する政治的儀式であった。 下の東京府民が未だそのような天皇の威光にあずかれていないこ とからの要望ということになる。

請願の行われた 7 月当時, 全国的にコレラが流行っており, 上 野公園への行幸は秋の涼しい時期に行いたい, というのが当局の 意向であったようだが，結局は 8 月に実施された。その理由は記 録には明記されてないが, 当時 7 月から 8 月にかけて来日中であっ
たグラント将軍 (元米大統領) の滞在日程に合わせたものと考え られる。その仕掛け役は福地である可能性が高い。福地は明治 3 年に伊藤博文 (明治 11 年より内務卿) と渡米し当時のグラント 大統領に謁見したほか豊富な海外経験を持ち, 今回のグラント将 軍の来日にむ重要なホスト役を務めていた。 ${ }^{34)}$ 既に将軍の歓迎会 や天皇との会見は行われていたが，天皇の東京府民に向けての 「巡幸」とそれを海外の眼にも知らしめるという一大イベントを 福地らは企画したのである。

行幸は, 当時仮の皇居となっていた青山御所から, 四谷, 半蔵 門, 桜田門, 幸橋, 新橋, 銀座, 京橋, 日本橋, から萬世橋を渡 り, 御成街道を進んで広小路から上野公園に入るという道順であっ た。最短ルートを使わずに銀座通りなどを取り込んだ，パレード そのあのに重点が置かれたルート設定であることは, 先の福地ら の請願文から推して知ることができる。また公園には 80 歳以上 の老人を招待するなど，明治元年に天皇が京都から東幸した際と 同じような ${ }^{355}$ 振舞いが見られ，この明治 12 年の行幸が，地方巡 幸と同じような意義を持って実際に行われたことがわかる。上野 公園は, そのパレードの「上がり」として, 外国要人の歓迎の場 を越えて, 天皇を視覚化する重要な儀礼の会場としてここであ位 置づけられた。こうした開園式, 博覧会から続く一連の儀礼的行 為によって, 帝都たる東京における上野公園の国家的性格が決定 的なむのとなったのではないだろうか。ここで見過ごせないのは， 形式的にせよ下からの請願に基づいた天皇の恩寵という手段を選 んだことで, これは明治政府が求めていた主体的存在としての国 民 ${ }^{36)}$ ，を演じさせる場を設けたということでもある。

公園内では中堂跡を会場として玉座や貴賓席が設けられ，そこ で槍剣術や流鏑馬などの武術の天覧があった。その背後では，本 坊跡（博覧会場跡）で新しい博物館の建設が始まっており，この 天覧は，先に述べた西欧型宮廷の庭園として公園を見立てた，博 物館の「前庭」での一大ページェントであったといえる。それは 空間的には第 1 回博覧会の美術館之庭園之の関係をさらに拡大さ せたもので，この構成が基本的には現在に続いている。

5. 天皇の空間の系譜 以上のように, 明治前期の上野公園に関 連した天皇の儀礼行為は, 公園の空間に強い影響を残したが, そ れが継承されていく姿を追ってみる。パレードの目的地としての 上野公園の国家的性格は, 明治 22 年の大日本帝国憲法発布の祝 典での，銀座通りからの行幸によって頂点に達した。下って明治 34 年に上野公園の管理者であった博物館は，公園がなお乱雑な

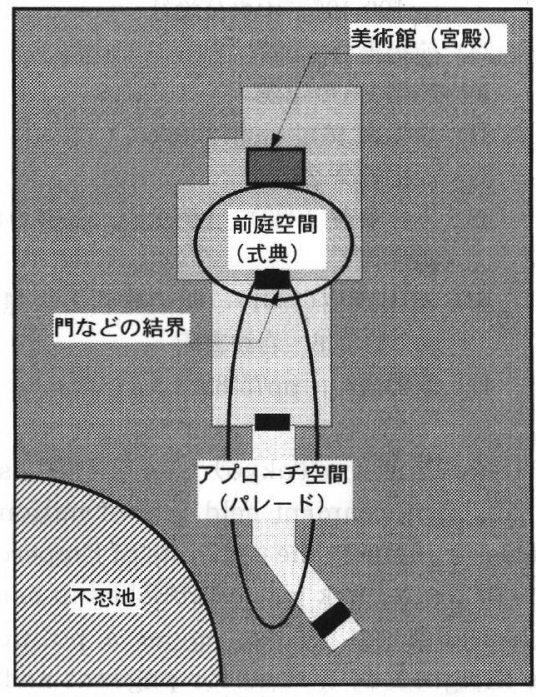

図 -3 第 1 回博覧会における儀礼的空間

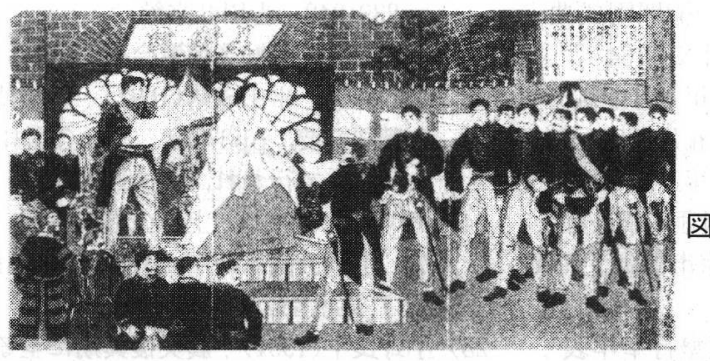

図-2『内国勧業博覧会開場 御式之図』橋本直義 明治10年

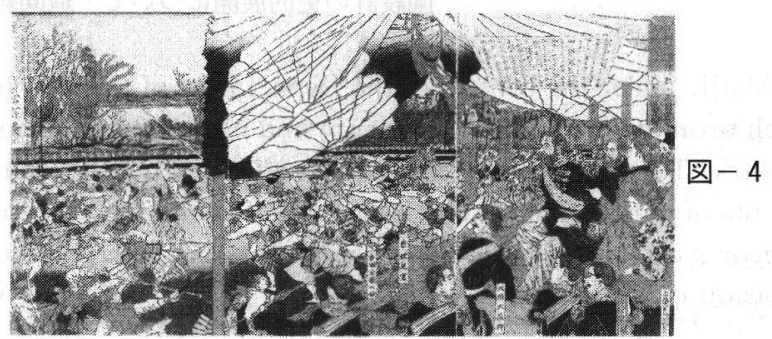

『上野公園地二於テ米 国前ノ大統領グラン 卜氏鎗術遊覧図』 古林栄成, 明治12年 
様子を呈していたため，上野公園修理調査委員会を設け，35 年 に報告を行っている。改修項目の一つとして,

「第四 : 三号館五号館习移転シタル上八竹ノ台全部 7 修理装飾 シテ之ヨ雄大宏闊ノ庭園トナシ中央二一大道路ヨ通シソノ左右ノ 広場二奏楽堂各一個ヨ建設スル事 $3^{37)}$ とている。竹の台は中堂 跡で, グラント将軍歓迎式が行われ，その後博覧会時には中心的 会場となっていた場所である。ここで博物館と前庭の関係ははっ きりと明文化されることとなった。

特に興味深いのはこの委員会に内匠橑技師の福羽冕人が関わっ ていたことである。福羽は明治 33 年のパリ博に参加して新宿植 物御苑の改造設計を仏造園家に依頼し, 自らは明治 36 年の第 5 回内国博の庭園を担当する身であった。その双方で，彼は御苑の 宮殿（実現せず）と博覧会の美術館前に展開する壮麗な造園計画 を立てており，これが大正期に彼の後継者の折下吉延によって， 明治神宮外苑に代表されるヴィス夕を取り入れた景観設計として 大成されていく。同時期に福羽が上野公園にも関わっていた事実 から，この造園デザインの系譜淿) の源流には, 天皇の儀礼空間と しての上野公園の空間が，その一脈をなしていたことがわかる。

さらに大正 13 年に上野公園は宮内省から東京市へ下付された が，そのときの条件の一つとして

「4. 博物館前指定/区域二八建築物 $ᄏ$ 建設セザルコト。博物 館近接/地域内二八可燃性建築物 $ᄏ$ 建設セザルコト。」 ${ }^{377}$ としてい る。条件の一つが第 1 回博覧会に始まる博物館と前庭の関係を後 世に存続させることにあり, 天皇を戴く「国家」により形作られ
た空間が「下付」されたことがわかる。そして震災後の新博物館 のコンペ（昭和 5 年）や, ${ }^{37)}$ 戦後になっても竹の台の噴水の整備 (昭和 35 年), 東京文化会館（昭和 36 年）などは ${ }^{39}$ すべてこの条 件に則り現在の上野公園に至っている。

\section{5. おわりに}

以上，天皇の儀礼を通して，上野公園の空間の形成の過程を分 析した。最初の開園式では, 徳川の遺産である上野の場听性を更 新するための儀礼が天皇により行われた。続けて開かれた内国勧 業博覧会では, 天皇の力を可視化する儀礼とそれに応じた空間が 実現され，その意思が明治 12 年の行幸に置いてさらに強化され， パレードの空間と, 西欧宮廷風の建築及び前庭の構成からなる, 現在につながる空間の基本骨格が形成された。

しかしこれらの儀礼の風景に, 民衆の姿としてはパレードの沿 道に群がる人影しか見ることができない。明治 22 年の憲法発布の 祝典の際も, 上野公園自体は華族や議員らのために使用されただ けで, 民衆はただ沿道から聖容を仰ぐのみであった。公園が民 衆の参集する祝典, イベント等の儀礼の場となるのは, 明治 27 年の日清戦争祝捷会辺りからであるが，このころから民衆の儀礼 の姿が, 明治20年代以降に帝都の整備とともに登場してきた宮城 外苑（明治21年から整備）や日比谷公園（明治36年）に現れてく る。これは形式的にも立憲君主制が確立してきたことや, 明治前 半期の巡幸という天皇の儀礼の形態の変化, あるいは天皇と国民 の間の視線の関係の変容 ${ }^{41}$ 等とも関わりのあることと考えられる。

\section{補注及び参考文献}

1) 小寺駿吉(1944）：上野恩賜公園一特に 明治文化史上に於けるその位置一：公 園史と風景論, 小寺駿吉論文集 pp3240

2 ) 田中正大(1974)：日本の公園 : 鹿島出 版会

3 ）吉見俊哉(1987）: 都市のドラマトゥル ギー, pp127-133, 弘文堂

4) 多木浩二(1988): 天皇の肖像: 岩波書 店

5) T・フジタニ(1994): 天皇のページェ ント, $240 \mathrm{pp}$ : 日本放送出版協会

6 ）宮内庁 (1969）：明治天皇紀 第三 pp598-599：吉川弘文館

7 ）丸山撰一(1996)：上野公園開園式典 120 周年事業 : 都市公園 No.134

8 ) 『東京日々新聞』明治九年五月十日

9 )『東京曙新聞』明治九年五月十日

10）『郵便報知新聞』明治九年五月十日

11）宮元健次 : 江戸の都市計画 : 講談社

12）東京市役所（1916）: 東京市史稿, 皇城 篇, 第四 : pp166-186

13）矢吹活禅(1933）明治天皇行幸年表 : 聖文閣
14）東京市役所(1932)：帝都復興祭志

15）前掲書3), p131

16）東京国立博物館(1973）: 東京国立博物 館百年史, p200：東京国立博物館

17）東京市役所(1932）：東京市史稿，遊園 篇，第四：p883に，許可を受けた者

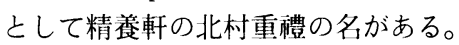

18）前嶋康彦(1960) 東京公園史話 14 : 都 市公園 23, pp25-29

19）上野の杜事典編集会議(1995)：上野の お山を読む, p97 : 谷根千工房

20）小野良平(1996）：明治初期の内国勧業 博覧会における会場デザインの思想 : ランドスケープ研究 59( 5 ), pp25-28

21）宮内庁(1970）: 明治天皇紀 第凶, pp239-242：吉川弘文館

22）明治十年内國勧業博覧会規則帖

23）田中芳男，平山成信（1897）: 渙國博覧 會参同紀要, pp37-39, 式は会場中央 大ドームで行われ，美術館等はない。

24）田中正大(1996）:上野公園の空間 構 造：上野公園ものがたり, pp52-61： （財）東京都公園協会

25）小野良平(1991）：震災復興期に至る公 園設計の史的展開について：造園雑誌
53( 5)，pp73-78，なお京都，大阪て は式場は常設の施設になっている。

26）農商務省(1883)第二回内国勧業博覧会 報告書, $\mathrm{pp} 7-13$

27）前掲書 4), pp6-10

28）明治十年内國勧業博覧会場案内：内國 勧業博覧会事務局, 1877

29）富田淳久訳(1875）：博覧会場建築比較 論：渙國博覧会報告書博覧会部下 $\mathrm{p} 46$

30）前掲論文 20）

31）前掲書 21)

32）東京市役所(1933）：東京市史稿，遊園 篇, 第五, pp261-293

33）前掲書 4), p80

34）小山文雄(1984）：明治の買才福地桜痴, pp100-106：中央公論社

35）前掲書4), p27

36）前掲書5), p26

37）前掲書 16), pp372-483

38）前掲論文 25）

39）小林安茂(1980）：上野公園，pp91-94： 郷学舎

40）遠山茂樹(1991）：明治維新と天皇, pp245-246: 岩波書占

41）前掲書4), pp75-89

Summary : In early Meiji, under the control of the Department of the Interior, Ueno Park (in Tokyo) was opened as a 'national' park which promote the national museum and national exhibition. And Goverenment held lots of national ceremonies at Ueno Park. This study aims to reveal the effects of public ceremonies, especially the pageants of Emperor, on spatial developments of parks in Meiji era. It is cleared that a spatial frame of Ueno Park was established in early Meiji. First, Emperor's ceremony renewed the national characteristics of Ueno district. Then, under a political necessity of visualization of Emperor for nation people, the Ueno Park was designed as a road for pageant and a palace-like garden. 